\title{
A laikus elsősegély szerepe a kórházon kívüli keringésmegállások túlélésében
}

\author{
Diószeghy Csaba dr. \\ Surrey and Sussex Healthcare, NHS Trust, Redhill, United Kingdom
}

\begin{abstract}
A váratlan szívhalál a fejlett országokban a halálozás egyik vezető oka. Bekövetkeztekor csak az azonnali ellátás mentheti meg a beteg életét. Az eszméletvesztéskor jelen lévő laikus tanú által alkalmazott egyszerú beavatkozással (CPR) a túlélés esélye jelentősen nő, mégis az eseteknek kevesebb mint a felében történik ilyen beavatkozás. Az utóbbi évek egyik legfontosabb felimerése az volt, hogy az alapfokú újraélesztés lépéseinek egyszerúsítése, az oktatás rövidítése és népszerüsítése szélesebb körben javíthatja a laikus segélynyújtás gyakoriságát és ezzel a túlélési esélyeket. A kezdeményezés valóban sikeres, és az utóbbi években számos tanulmánynak sikerült kimutatnia a laikus újraélesztés gyakoribbá válását a világban, Európában és hazánkban is. A túlélési mutatók kismértékű javulása is tetten érhető, ugyanakkor még mindig jelentősen elmarad az ideális körülmények között elérhetőtől. A jelen összefoglaló áttekinti azokat a szempontokat, amelyek a laikus segélynyújtás mennyiségi és minőségi javulását eredményezhetik hosszabb távon. Orv Hetil. 2019; 160(46): 1810-1815.
\end{abstract}

Kulcsszavak: kórházon kívüli keringésmegállás, túlélés, laikus újraélesztés, oktatás

\section{The role of bystander resuscitation in the survival of out-of-hospital cardiac arrests}

Sudden cardiac death is one of the leading causes of mortality in developed countries. When happens only immediate action can save the patient's life. A rather simple sequence of interventions (CPR - cardiopulmonary resuscitation) by the bystander witnessing the collapse could significantly increase the chance of survival yet it happens less than in half of the cases. One of the most important initiatives of the last decade was the simplification of basic life support guidelines and its trainings along with widely publicising its simplicity, importance and its effect on survival. The success of the initiative has been published by several studies showing an increasing number of bystander CPR worldwide, in Europe and in Hungary, too. Survival data have also increased moderately but by far not as much as it could be expected under ideal circumstances. This paper reviews the potential issues to be considered for increasing the numbers and improving the quality of bystander resuscitation.

Keywords: out-of-hospital cardiac arrest, outcome, bystander resuscitation, training

Diószeghy Cs. [The role of bystander resuscitation in the survival of out-of-hospital cardiac arrests]. Orv Hetil. 2019; 160(46): 1810-1815.

(Beérkezett: 2019. július 21.; elfogadva: 2019. augusztus 22.)

\section{Rövidítések}

AED = (automated external defibrillator) automata külső defibrillátor; ALS = (advanced life support) emelt szintű újraélesztés; BLS = (basic life support) alapszintű újraélesztés; $\mathrm{CPR}=$ (cardiopulmonary resuscitation) szív-tüdő újraélesztés; EPSF $=($ European Patient Safety Foundation $)$ Európai Betegbiztonsági Alapítvány; ERC $=($ European Resuscitation Council) Európai Resuscitatiós Tanács; EuReCa = (European Registry of Cardiac Arrest) Európai Keringésmegállási Jegy- zék; KSL = (Kids Save Lives) „Gyermekek életeket mentenek”; $\mathrm{PAD}=$ (Public Access Defibrillation) Nyilvános hozzáférésû́ defibrillálás; WHO = (World Health Organization) Egészségügyi Világszervezet

A kórházon kívüli váratlan keringésmegállások gyakorisága évente 53-112/100 000 lakos között változik a világban, és a fejlett régiók egyik vezető haláloka még nap- 
jainkban is: az összes halálozás mintegy 15-20\%-áért felelős [1]. Magyarországon évente közel 9000 esethez riasztják a mentőket [2]. Régóta tudjuk, hogy amennyiben a túlélési lánc ideálisan megvalósul, a kórházon kívüli váratlan keringésmegállások túlélése akár az 50-70\%-ot is elérheti [3]. Ezzel szemben a 27 országban 2014 októberében végzett EuReCA-1 vizsgálat eredményei szerint Európában a 30 napos túlélés átlagosan 10,3\% volt az összesen 6414 újraélesztés adatai alapján és az országok közötti meglehetősen nagy szórás mellett [4]. Hazánkban a vizsgálatba bevont időszak és a térség adatai szerint 127 keringésmegállásból 85 esetben kezdtek újraélesztést, és a 30 napos túlélés 10,2\% volt, ami éppen megfelel az európai átlagnak.

A túlélés javítására tett kísérletek az elmúlt fél évszázadban a túlélési lánc köré csoportosultak, és a korai alapfokú újraélesztést (BLS), korai defibrillálást, a magas szintű újraélesztést és gyógyszeres terápiát (ALS), valamint a postresuscitatiós intenzív ellátást igyekeztek javítani. A nagyarányú kutatások, nemzetközi konszenzusok alapján kialakított eljárási protokollok ellenére 2010-ig a túlélés 30 év alatt alig változott [5]. Ez az elszomorító tendencia azonban, úgy túnik, változni kezdett: egy kanadai vizsgálatban 2006 és 2013 között 23619 betegen végzett, kórházon kívüli újraélesztés túlélése 2006-ban 4,8\% volt, ám 2013-ra 9,4\%-ra növekedett ( $\mathrm{p}<0,0001)$. A statisztikai analízis alapján a túlélés szignifikáns növekedése a laikus újraélesztés (35,7\%-ról 43,7\%-ra; $\mathrm{p}<0,001)$, a laikus által alkalmazott AED (7,49\%-ról 15,47-re; $\mathrm{p}<0,0001)$, valamint a postresuscitatiót követő hőmérsékletkontroll-terápiák （40,5\%-ról 58,2\%-ra; $\mathrm{p}<0,0001)$ fokozott elterjedésének volt köszönhető [6]. Ezek a bátorító eredmények azonban még mindig jelentősen elmaradnak az ideálisan elvárható túléléstől.

Európában a váratlan keringésmegállások többsége, mintegy 70\%-a lakásban történik, és az összes eset több mint felében $(54,3 \%)$ van jelen tanú [4]. Az ellátás megkezdése éppen ezért a helyszínen levő és az eseményt észlelő laikusokra hárul, és - mint azt már többen leírták - a laikusok megfelelő beavatkozása döntő jelentőségú ilyenkor [7]. A túlélési lánc ezen első láncszeme, azaz a laikus BLS kivitelezése a mentők kiérkezése előtt ugyanis megsokszorozza a túlélés esélyét. A laikusok bevonása ezért a kórházon kívül bekövetkezett váratlan keringésmegállások ellátásába elengedhetetlen és a túlélés esélyeit meghatározó feladat $[5,7-9]$.

\section{A laikus újraélesztés gyakorisága: a mennyiség}

Nem teljesen egyértelmü, hogy az esetek milyen hányadában kezdenek meg laikusok újraélesztést (BLS). Elöször is nem tudjuk, hogy hány alkalommal történik élesztési kísérlet a mentő kiérkezése előtt, amit aztán a segélynyújtó valamilyen okból kifolyólag abbahagy. Másrészt nem tudjuk, hogy mikor mit is értenek élesztési kísérleten, és a különböző statisztikai jelentések sokszor egymással nem összevethető definíciókat használnak. Jobbára ugyan a mellkasi kompressziók meglétéhez kötik a BLS megkezdését, de például gyermekek esetében a lélegeztetés egyedüli alkalmazása is jogosan tekinthető élesztési kísérletnek. Ugyancsak nem ismert, legfeljebb becsült adat az, hogy az összeesés és a szemtanú által megkezdett újraélesztési kísérlet között mennyi idő telt el. A segélynyújtás „megkezdése” és az első mellkasi kompressziók kivitelezése között ugyanis jelentős idő telhet el akár a betegvizsgálattal, segélyhívással vagy csak a megfelelő döntés meghozatalával is. További nehézség a laikus segélynyújtások értékelésében az, hogy azok törvényszerûen nem szakemberek jelenlétében folynak, így hatékonyságuk, illetve minőségük alapvetően meghatározhatatlan. Szimulációs kísérletek ugyan képesek mérni a laikusok pszichomotoros készségeit (a kompressziók mélységét, frekvenciáját, a kompressziós pontot, a lélegeztetés hatékonyságát stb.), de ez csupán távolról következtet a valós környezetben zajló újraélesztés minőségére. Mindezek ellenére a világon már számos helyen múködő resuscitatiós adatbázisokban a mentők által rögzített megfigyelés (ami a modern adatbázisok esetén a mellkasi kompressziókhoz köti a laikus BLS meglétét) alkotja a laikus elsősegélynyújtás mennyiségét legjobban becslő értéket. Ezek alapján az Amerikai Egyesült Államokban 50,6\%, az Egyesült Királyságban (UK) 66\% a laikus elsősegély gyakorisága azokban az esetekben, amikor a kórházon kívüli keringésmegállás nem a mentők jelenlétében történt $[9,10]$. Az EuReCA-1 vizsgálat szerint a laikusok Európában átlagosan 47,4\%-ban kezdenek újraélesztést, és ebben hazánk a középmezőnyben szerepel (Magyarország: 43,6\%) [2,4].

Bár az újraélesztések kimenetelében a postresuscitatiós kezelés fontossága kapott egyre nagyobb hangsúlyt és figyelmet az utóbbi két évtizedben [11], mégis talán az egyik legnagyobb hatású fejlesztés az újraélesztésben az volt, amikor a laikus segélynyújtást a tömegek felé egyszerüsítették, demisztifikálták. A nagyszabású és komplex életmentő múvelet és képzett segélynyújtókat igénylő „beavatkozás” helyébe egyszerü, bárki által elvégezhető és elvégzendő cselekvéssor lépett, amelyet akár vicces videókon, YouTube-csatornákon, tévében népszerúsíthettek. A Vinnie Jones-féle „Staying alive” zenéjére történő mellkasi kompressziók vagy a „Super Sexi CPR" YouTube-videó is mind azt a célt szolgálta, hogy elvegye a BLS-től a félelmetesen hangzó „újraélesztés” imázsát, és egyszerűbb „segítségnyújtás”-ra átkeretezve azt a képzett egészségügyi ellátóktól átadja mindenki kezébe [12, 13]. A lélegeztetés elhagyásával ugyancsak azt érték el, hogy az egész múvelet még egyszerübbé és ezzel még könnyebben vállalhatóvá vált mindenki számára. Az oktatás kiterjesztése, tömeg-CPR-oktatások szervezése stadionokban vagy meccsek szüneteiben, a pár perces önképző videók és okostelefonos applikációk mellett a mentőszolgálatok telefonos CPR-tanácsai is azt segítették elő, hogy a laikusok beavatkozzanak és megkezdjék az újraélesztést. Kragholm (Dánia) vizsgálatában 2001 
és 2016 között a kampány eredményeképpen a laikus újraélesztés 66,7\%-ról 80,6\%-ra ( p<0,001), míg az AEDhasználat 2,1\%-ról 16,8\%-ra $(\mathrm{p}<0,001)$ emelkedett, ezzel párhuzamosan a 30 napos túlélés 3,9\%-ról 12,4\%-ra $(\mathrm{p}<0,001)$ nött [8].

A laikus elsősegélynyújtás gyakoriságáról fellelhető magyarországi adatok az Országos Mentőszolgálat által gyưjtött adatbázisból származnak. A 2004-ben közölt (a 2003. évre vonatkozó) adatok szerint akkor a laikusok az általuk észlelt keringésmegállások 22\%-ában kezdtek újraélesztést [14]. A 2015-ben feldolgozott éves adatok körülbelül azonos számú újraélesztést regisztráltak (2013-ban 8500, 2015-ben 8652), továbbá a lakáson és közterületen bekövetkező keringésmegállások aránya is hasonló volt ( $70 \%$ versus $72 \%$ lakáson). 2015-ben azonban a laikusok az általuk észlelt esetek 43,6\%-ában kezdtek el újraélesztést, ami nagyjából duplája a 12 évvel ezelőtti gyakoriságnak. Ami meglepő, hogy a kórházban élve átadott betegek aránya 2003-ban 20\%, míg 2015ben is csupán $21 \%$ volt $[2,14]$. Ez minimális javulás ugyan, de nincs arányban a laikus újraélesztések gyakoriságának jelentős emelkedésével.

\section{A mennyiség és a minőség kérdése az újraélesztésben}

Ideális esetben a keringésmegállás bekövetkeztét követő perceken belül megkezdődik a BLS, amelynek során mellkasi kompressziókkal a mesterséges keringést tartjuk fenn, míg mesterséges lélegeztetéssel a keringő vér oxigenizációját biztosítjuk. A 2000-es évek első évtizedének egyik fontos vitatémája volt, hogy egyáltalán szükséges-e ilyenkor lélegeztetni, és nem elég-e csupán mellkasi kompressziókkal fenntartani a keringést addig, míg a defibrillálás vagy eszközös újraélesztés meg nem érkezik. A jelen cikk nem akarja ismét összefoglalni azokat az evidenciákat, amelyek arra a konszenzusra jutottak, hogy a lélegeztetés az újraélesztés első $5-8$ percében nélkülözhető ugyan a szíveredetű keringésmegállások első ellátásában, de az ennél tovább elhúzódó BLS esetén a hypoxia már nem tolerálható tovább, és a lélegeztetés elmaradása rontja az esélyeket. Ennek megfelelően tudjuk, hogy a semminél ugyan jobb a mellkasi kompressziók lélegeztetés nélküli alkalmazása, de az 5-8 percnél tovább elhúzódó BLS esetén a lélegeztetéssel együttes kompressziók jobb esélyt biztosítanak a csak kompressziókkal történő újraélesztésnél [15]. A mentésirányítás által telefonon keresztül diktált újraélesztés is csak a mellkasi kompressziókat végezteti el, ami tehát jelentősen növeli a laikus beavatkozások mennyiségét, de nem feltétlenül párosul minőséggel.

Pedig a kompressziók minősége sem mellékes szempont. Számos vizsgálat bemutatta, hogy a túlélés jobb volt azokban az esetekben, amikor az elsősegélynyújtást képzett szakember végezte, és nem teljesen laikus [1618]. Ez arra enged következtetni, hogy a jobb minőségú resuscitatio a túlélés szempontjából fontos előny [19].
A jó minőségű mellkasi kompressziók kivitelezése nem ördögien bonyolult, és számos tanulmány igazolta, hogy az ehhez szükséges pszichomotoros készség nagyon rövid idő alatt elsajátítható. A megfelelő lélegeztetési technika elsajátítása már valamivel nehezebb, de rövid tanfolyamokon ez is megtanulható.

Figyelemre méltó az is, hogy bár a nemzetközi adatokban a 40\% körüli laikus újraélesztési gyakoriság ma már az átlag, az automata defibrillátorok alkalmazása a laikusok által még most is ritkaság. A mentők kiérkezése előtt a betegeknek csupán a 2,3\%-át defibrillálják az UKban, és hasonló, 2,2\% a gyakoriság Magyarországon is $[2,20]$.

A laikus BLS egyszerúsítése, a lélegeztetés szerepének leértékelése és ezzel a BLS fentebb is említett módon történő elterjesztése nagyon sikeresen emeli tehát a laikus segélynyújtások mennyiségét, de a minőséget nem befolyásolja, vagy akár ronthatja is, ha a széles kampány arra ösztönöz egyébként teljes BLS-képzésben részt vett segélynyújtókat, hogy csak kompressziókkal is azonos hatást érnek el. Ezzel az elvileg teljes BLS-re képes segélynyújtó is csak a limitált újraélesztést fogja végezni, ami - ha a mentő nem érkezik meg pár percen belül már gyengébb hatásfokú, mint az amúgy általa alkalmazható teljes BLS. Ugyancsak nem sikerült elérni az egyébként már egyre szélesebb körben hozzáférhető AED-k használatát, a PAD- (Public Access Defibrillation) programok és a közterületen elhelyezett készülékek megismerését és felismerését szolgáló kampányok, okostelefonos applikációk vagy a mentők által a bejelentőnek adott információk ellenére sem. Ezért a kampány sikere csak akkor várható, ha a megfelelően képzett és felszerelt segítség 5-8 percen belül rendelkezésre áll. Egy lassan reagáló mentőszervezet mellett a laikusok ilyen jellegű szerepvállalása minimális hatékonyságú marad.

\section{Oktatás és felejtés (skill retention)}

A laikus segélynyújtás mennyiségi, de fóleg minőségi mutatóinak javításában a megfelelő oktatás elengedhetetlen szerepet játszik. A kérdés az, hogy kinek, mikor, mit és hogyan oktassunk. A BLS elterjedését az segíti, ha minél több embernek lehetőleg egyszerüen, gyorsan és minél kevesebbet oktatunk. A BLS-irányelvek egyszerüsítése és a csak mellkasi kompressziókat oktató gyors és egyszerú oktatási modellek a laikus BLS elterjedését nagyban segítették. A teljes BLS-képzést (amely magában foglalja a befúvásos lélegeztetés oktatását is) lépcsőzetes módon oktató rendszerekben az alapgondolat az, hogy az első körben csak mellkasi kompresszióra oktatott hallgatók nagy hányada szerezhet kellő motivációt arra, hogy a további lépéseket is megtanulja, és részt vegyen a „teljes” BLS-tanfolyamon, ahol a lélegeztetést és az AED-használatot is elsajátíthatja [21].

Az ilyen képzések tipikusan 2-4 órás foglalkozások kis-közepes (4-12 fös) csoportokban, és egyszerü BLSfantomokon történnek egy vagy legfeljebb két oktató 
jelenlétében. A strukturált képzések sokszor követik a "kevés alapozó elmélet - demonstráció - gyakorlás” irányt, és a gyakorlati rész gyakran az Európai Resuscitatiós Tanács és a Magyar Resuscitatiós Társaság tanfolyamain is használt négylépcsős módszert követi, amely megfelelően hatékony akár komplexebb pszichomotoros készségek oktatásában is. A BLS-tanfolyamok végén többnyire nem tartanak formális vizsgát, és irodalmi adatok azt mutatják, hogy az ilyen 2-4 órás képzések megfelelő készséget biztosítanak teljesen laikus közönség számára is. Ami még ennél is fontosabb: ezek a képzések a vizsgálatok eredménye szerint segélynyújtási motivációt és a segélynyújtó magabiztosságát is növelni tudták. Sajnos azonban ez csak korlátozott keretek között és csak korlátozott ideig érvényes. Amennyiben ugyanis a képzésre eleve motiválatlan hallgatók jönnek, esetleg a képzést valamilyen más jellegű eredmény eléréséhez kötve teszik kötelezővé (például az autóvezetői engedély megszerzésének feltétele), a tanfolyam hatása a motivációra és az önbizalomra már sokkal kérdésesebb [22]. $\mathrm{Az}$ is bizonyított tény, hogy a tanfolyamokon szerzett készségek, amennyiben nem használják azokat rutinszerüen, 3-6 hónapon belül jelentősen kopnak, illetve akár teljesen el is tûnhetnek [23-25]. Ez ellen a frissítő képzések (félévente vagy évente) hatékonyan alkalmazhatók, de még akkor is hatalmas terhet rónak az oktatásra, ha a frissítés csak egy nagyon rövid (1 órás) gyakorlati foglalkozás formájában zajlik. Valamit enyhít azonban ezen a terhen, ha a készségek frissítése nem formális foglalkozás, hanem akár videón keresztül (DVD vagy számítógépes szoftver) adott instrukciókkal zajló önképzés kereteiben otthon történik meg [26]. Az ehhez szükséges anyagot (például DVD), valamint a gyakorláshoz szükséges egyszerüsített szimulátort (fantom) akár az első formális tanfolyamon is át lehet adni.

A BLS-oktatás azonban még akár ezeknél is lehet egyszerúbb, és az irodalomban se szeri, se száma azoknak a közleményeknek, amelyek a minél egyszerúbb, minél rövidebb és kisebb infrastruktúrát igénylő képzések hatékonyságát demonstrálják [27-29]. Közös ezekben a régi és új formátumú képzésekben, hogy a képzés végére és tipikusan az azt követő 3-6 hónapra a laikusok szert tesznek arra a készségre, hogy elméletben felismerjenek egy váratlan keringésmegállást, és pár percen keresztül képesek legyenek megfelelő hatékonyságú mellkasi kompressziókat végezni, illetve a magasabb szintű képzések esetén képesek befúvásos lélegeztetést is alkalmazni (kérdéses hatékonysággal), sőt eszükbe jut és alkalmazni tudják a rendelkezésre álló AED-t.

\section{Az emberi oldal}

Azok a laikusok, akik valamilyen képzésen már részt vettek, motiváltabbak is a segítségnyújtásra, és kérdőíves vizsgálatok tanúsága szerint nagyobb önbizalommal is rendelkeznek, ezért várhatóan nagyobb eséllyel fognak adott esetben hatékonyan beavatkozni $[30,31]$. A valódi újraélesztésekben részt vett laikus segélynyújtók körében végzett felmérések azonban azt sugallják, hogy a legnagyobb nehézség nem a fizikai készség vagy a megfelelő motiváció megléte volt, hanem a helyzet felismerése és az újraélesztés megkezdéséhez szükséges döntés meghozatala [32]. A tanfolyamok és a BLS-t népszerüsítő kampányok könnyed légkörével és a szimulációkon használt eszközökkel ellentétben ugyanis a valós helyzet kiábrándítóbb és ijesztóbb is. A laikus - még ha erról beszéltek is a tanfolyamokon - többnyire nincs felkészülve a keringésmegállásban lévő áldozat bőrszínének hirtelen (és ijesztő) változására, esetleg hangok vagy váladék megjelenésére és az agonális légzés (gasp) látványára sem. A valóságban észlelt kép nem emlékeztet sem a szimulációkon használt mozdulatlan, pirospozsgás müanyag babákra, sem az egyszerúsített fantomok emberre nem igazán hasonlító mellkastorzóira. Még fontosabb szempont azonban, hogy az áldozat többnyire nem személytelen, ismeretlen „fantom”, hanem sokszor a segélynyújtó által ismert személy vagy akár családtag. Ezért az összeesést észlelő laikus sokáig nem akarja elhinni, hogy a legroszszabb történik, és még amikor felismeri is a keringésmegállást, a döntés a BLS megkezdéséról nehezebb, mint gondolnánk. A hezitálás, abban reménykedve, hogy még sincs akkora baj, súlyos időveszteséget okoz, ami jelentősen ront az esélyeken. A hezitálásnak számos oka van, az egyik a helyzet tudat alatti tagadása, de a másik az, hogy a legtöbb laikus számára többé-kevésbé ismeretlen helyzetet jelentenek a sürgősségi szituációk, a gyors helyzetfelismerés és döntési kényszer. Éppen ezért sokan pánikkal reagálnak egy krízisszituációra, ami megbénítja a helyzet elemzéséhez és a döntéshozatalhoz szükséges készséget. Úgy túnik, hogy a laikus újraélesztés egyik legnehezebb része nem is a mellkasi kompreszsziók vagy a lélegeztetés megfelelő kivitelezése, hanem a felismerés és a döntés késedelem nélküli meghozatala lehet. Erre felkészülni egy felnőtt laikusok számára tartott rövid tanfolyam során aligha lehetséges, sokkal inkább komplex gondolkodásmód vagy kultúra kérdése.

\section{A jövő: „Kids Save Lives”}

A motiváció és a pszichomotoros készség mellett tehát a krízishelyzetben való helytállás és döntéshozatal képessége is fontos eleme a hatékony laikus segélynyújtásnak. Ennek a viselkedésformának a beépülése személyiségünkbe nagy előnyt jelent, és nyilvánvalóan nem csak a váratlan keringésmegállások túlélésének tekintetében. Az újraélesztés egyszerü pszichomotoros készsége már iskoláskorban is hatékonyan oktatható [33]. A pubertás előtti korban kezdett képzés további előnye, hogy a felelősségvállalás képessége, a segélynyújtás és az altruizmus ösztöne és az önbizalom is sokkal hatékonyabban fejleszthető, mint felnőttkorban, és ezzel a krízishelyzetekhez való alkalmazkodás készsége is kialakul. Az iskolák természetükból adódóan kiváló környezetet adnak arra, hogy rendszeresen ismétlődő képzésekkel a gyermekek 
fejlődésének részévé tegyék ezt a készséget. Az Egészségügyi Világszervezet (WHO) 2015-ben támogatását adta ahhoz a javaslathoz melyet a European Patient Safety Foundation (EPSF) kezdeményezésével több nemzetközi szervezet (köztük az ERC) adott ki az újraélesztés iskolai oktatásáról. Ebben a „Gyermekek életeket mentenek" (Kids Save Lives - KSL) kezdeményezésben a WHO azt javasolja, hogy a gyerekeket 12 éves kortól felfelé évente legalább 2 órában minden iskolában oktassák a keringésmegállás felismerésére, a segítség hívására és a hatékony mellkasi kompressziók kivitelezésére. Európában a kezdeményezés hatására már 6 országban (Belgium, Dánia, UK, Franciaország, Olaszország és Portugália) az alaptanterv (vagy az annak megfelelő törvényi szabályozás) részévé vált ez a képzés, és további 22 európai országban (köztük hazánkban is) hivatalosan napirenden van, vagy ilyen irányú javaslatot nyújtottak már be [34].

A gyermekek képzésének részévé tett rendszeres újraélesztés-oktatás véleményem szerint a döntő és legfontosabb lépés a kórházon kívüli váratlan keringésmegállások túlélésének jelentős, hosszú távú és fenntartható javítására, de nagy valószínűséggel számos további haszonnal is jár majd: egy olyan generáció nőhet fel, amelynek tagjai nemcsak az okostelefonokat használják magától értetődő könnyedséggel, de a krízishelyzetekben is könnyebben reagálnak megfelelően, és embertársaik felé is magától értetődőbb módon nyújtanak majd segítő kezet.

\section{Következtetés}

A kórházon kívüli váratlan keringésmegállások túlélése az elmúlt évtizedben kismértékben javulni kezdett. Ennek a javulásnak egy része a megnövekedett arányú laikus elsősegélynyújtásnak tudható be. Az elmúlt évtized legnagyobb hatású lépése a reanimatológiában éppen a laikusok számra egyszerúbbé tett, demisztifikált és mind szélesebb körben népszerüsített újraélesztési modell volt, amely - a mentésirányítás általi telefonos CPR elterjedésével együtt - megduplázta a segélynyújtás gyakoriságát. A képzések sokszínúek, egyszerúbbek, és mind kevesebb infrastruktúrát igényelnek. Ugyanakkor szembetûnő, hogy a túlélési mutatók a nagyobb arányú laikus beavatkozáshoz képest a várhatónál lényegesen kevésbé javultak, aminek egyik oka a mennyiség növekedésével még nem párhuzamos minőségi javulás. A csak mellkasi kompressziókat végző laikus újraélesztés hatása a túlélésre meredeken csökken, ha a professzionális segítség nem érkezik meg 5-8 percen belül. Másrészt a laikus segélynyújtás hatékonyságát nagymértékben meghatározza a keringésmegállás bekövetkezte és a segélynyújtás megkezdése között eltelő idő, amely pedig a segélynyújtó krízishelyzetben történő döntéshozatali képességének is függvénye. Az utóbbi pedig több mint az újraélesztési tanfolyamokon elsajátítható pszichomotoros készség. Ezt a készséget fejlesztheti a korán, már iskoláskorban elkezdett és rendszeresen ismételt képzés, amely, ha a
WHO által is javasolt módon minden iskolai oktatás szerves részévé válik, esélyt adhat egy olyan generáció felnövéséhez, amely sürgős szükség esetén hamarabb és jobban fog tudni beavatkozni. Ha mindehhez sikeresen tudjuk a túlélési lánc további szemeit füzni, és első lépésként a professzionális segítség érkezéséig eltelő időt 8 perc alá rövidíteni, majd a resuscitatiót követő időszak komplex intenzív ellátását is biztosítani [35], a kórházon kívüli váratlan keringésmegállások túlélési esélyei érdemben javulhatnak.

Anyagi támogatás: A közlemény megírása és az ahhoz kapcsolódó munka anyagi támogatásban nem részesült.

A szerző a cikk végleges változatát elolvasta és jóváhagyta.

Érdekeltségek: A szerzőnek nincsenek a közleményt érintő érdekeltségei.

\section{Irodalom}

[1] Hayashi M, Shimizu W, Albert CM. The spectrum of epidemiology underlying sudden cardiac death. Circ Res. 2015; 116: 1887-1906.

[2] Gőbl G. Unpublished data, personal communication 2015. [„Utstein-adatbázis - OMSZ 2015.”] Országos Mentőszolgálat, Budapest, 2015. [Hungarian]

[3] Valenzuela TD, Roe DJ, Nichol G, et al. Outcomes of rapid defibrillation by security officers after cardiac arrest in casinos. $\mathrm{N}$ Engl J Med. 2000; 343: 1206-1209.

[4] Gräsner JT, Lefering R, Koster R, et al. EuReCa ONE - 27 Nations, ONE Europe, ONE Registry: a prospective one month analysis of out-of-hospital cardiac arrest outcomes in 27 countries in Europe. Resuscitation 2016; 105: 188-195. Corrigendum: Resuscitation 2016; 109: 145-146.

[5] Sasson C, Rogers MA, Dahl J, et al. Predictors of survival from out-of-hospital cardiac arrest: a systematic review and meta-analysis. Circ Cardiovasc Qual Outcomes 2010; 3: 63-81.

[6] Buick JE, Drennan IR, Scales DC, et al. Improving temporal trends in survival and neurological outcomes after out-of-hospital cardiac arrest. Circ Cardiovasc Qual Outcomes 2018; 11: e003561

[7] Böttiger BW, Lockey A, Aickin R, et al. "All citizens of the world can save a life" - The World Restart a Heart (WRAH) initiative starts in 2018. Resuscitation 2018; 128: 188-190.

[8] Kragholm K, Wissenberg M, Mortensen RN, et al. Bystander efforts and 1-year outcomes in out-of-hospital cardiac arrest. N Engl J Med. 2017; 376: 1737-1747.

[9] Kurz MC, Schmicker RH, Leroux B, et al. Advanced vs. basic life support in the treatment of out-of-hospital cardiopulmonary arrest in the Resuscitation Outcomes Consortium. Resuscitation 2018; 128: 132-137.

[10] Brown T, Hawkes C, Booth S, et al. Temporal changes in bystander cardiopulmonary resuscitation rates in England. Resuscitation 2017; 118(Suppl 1): e69.

[11] Pilecky D, Szudi G, Kovács E, et al. The role of therapeutic hypothermia in post-resuscitation care - review of the literature and personal experience. [A terápiás hypothermia szerepe a postresuscitatiós ellátásban - irodalmi áttekintés és saját tapasztalatok.] Orv Hetil. 2016; 157: 611-617. [Hungarian]

[12] British Heart Foundation. Vinnie Jones: Hard and Fast - handsonly cardiopulmonary resuscitation (CPR). NHS-UK, 2012. 
Available from: https://www.nhs.uk/video/Pages/vinniejones-how-to-perform-cpraspx [accessed: 14 June, 2019].

[13] Fortnight, Super Sexy CPR. SuperSexyCpr.com, 2010. Available from: https://www.youtube.com/watch?v=yuYYpu5Qnu4 [accessed: 14 June, 2019].

[14] Gőbl G, Gáspár T. First review of the out-of-hospital chapter of the National Resuscitation Database: experience of eighteen months. [A nemzeti resuscitatiós adatbázis kórházon kívüli részének első értékelése: másfél év tapasztalatai.] Újraélesztés 2004; 2: 132-136. [Hungarian]

[15] Hazinski MF, Nolan J, Aickin R, et al. Part 1: Executive summary: 2015 international consensus on cardiopulmonary resuscitation and emergency cardiovascular care science with treatment recommendations. Circulation 2015; 132(Suppl 1): S2-S39.

[16] Herlitz J, Svensson L, Holmberg S, et al. Efficacy of bystander CPR: intervention by lay people and by health care professionals. Resuscitation 2005; 66: 291-295.

[17] Hansen CM, Kragholm K, Pearson DA, et al. Association of bystander and first-responder intervention with survival after outof-hospital cardiac arrest in North Carolina, 2010-2013. JAMA 2015; 314: 255-264.

[18] Park YM, Shin SD, Lee YJ, et al. Cardiopulmonary resuscitation by trained responders versus lay persons and outcomes of out-ofhospital cardiac arrest: a community observational study. Resuscitation 2017; 118: 55-62.

[19] Christenson J, Andrusiek D, Everson-Steward S, et al. Chest compression fraction determines survival in patients with out-ofhospital ventricular fibrillation. Circulation 2009; 120: 12411247.

[20] Hawkes C, Booth S, Ji C, et al. Epidemiology and outcomes from out-of-hospital cardiac arrests in England. Resuscitation 2017; 110: 133-140.

[21] Bogár L, Diószeghy Cs, Fülesdi B, et al. The Hungarian Resuscitation Council's Statement on Education of Resuscitation. [A Magyar Resuscitatiós Társaság állásfoglalása az újraélesztés oktatásáról.] Újraélesztés 2004; 2: 115-123.Hungarian]

[22] Uber A, Sadler RC, Chassee T, et al. Does non-targeted community CPR training increase bystander CPR frequency? Prehospital Emerg Care 2018; 22: 753-761.

[23] Nishiyama C, Iwami T, Kitamura T, et al. Long-term retention of cardiopulmonary resuscitation skills after shortened chest compression-only training and conventional training: a randomized controlled trial. Acad Emerg Med. 2014; 21: 47-54

[24] Riegel B, Nafziger SD, McBurnie MA, et al. How well are cardiopulmonary resuscitation and automated external defibrillator skills retained over time? Results from the Public Access Defibrillation (PAD) Trial. Acad Emerg Med. 2006; 13: 254-263.
[25] Woollard M, Whitfield R, Smith A, et al. Skill acquisition and retention in automated external defibrillator (AED) use and CPR by lay responders: a prospective study. Resuscitation 2004; 60: 17-28.

[26] Roppolo LP, Pepe PE, Campbell L, et al. Prospective, randomized trial of the effectiveness and retention of 30-min layperson training for cardiopulmonary resuscitation and automated external defibrillators: the American Airlines Study. Resuscitation 2007; 74: 276-285.

[27] Lynch B, Einspruch EL, Nichol G, et al. Effectiveness of a 30min CPR self-instruction program for lay responders: a controlled randomized study. Resuscitation 2005; 67: 31-43.

[28] Yuksen C, Sawatmongkornkul S, Tuangsirisup J, et al. The CPR outcomes of online medical video instruction persus on-scene medical instruction using simulated cardiac arrest stations. BMC Emerg. Med. 2016; 16: 25.

[29] Bjørnshave K, Krogh LQ, Hansen SB, et al. Abstract 262: Teach ing laypersons BLS and AED using a two-stage teaching technique is non-inferior to four-stage teaching technique: a randomized controlled study. Circulation 2013; 128(Suppl 22): A262.

[30] Tanigawa K, Iwami T, Nishiyama C, et al. Are trained individuals more likely to perform bystander CPR? An observational study. Resuscitation 2011; 82: 523-528.

[31] Cho GC, Sohn YD, Kang KH, et al. The effect of basic life support education on laypersons' willingness in performing bystander hands only cardiopulmonary resuscitation. Resuscitation 2010; 81: 691-694.

[32] Mausz J, Snobelen P, Tavares W. “Please. Don't. Die.” A grounded theory study of bystander cardiopulmonary resuscitation. Circ Cardiovasc Qual Outcomes 2018; 11: e004035.

[33] Plant N, Taylor K. How best to teach CPR to schoolchildren: a systematic review. Resuscitation 2013; 84: 415-421.

[34] Schroeder DC, Ecker H, Wingen S, et al. "Kids Save Lives" resuscitation training for schoolchildren. Systematic review. [ „Kids Save Lives“ - Wiederbelebungstrainings für Schulkinder. Systematische Übersichtsarbeit.] Anaesthesist 2017; 66: 589597. [German]

[35] Kovács E, Jenei Zs, Horváth A, et al. Physiologic effects of hypothermia. [A hypothermia élettani hatásai.] Orv Hetil. 2011; 152: 171-181. [Hungarian]

(Diószeghy Csaba dr., Surrey and Sussex Healthcare, NHS Trust, Redhill, UK e-mail: cdioszeghy@aol.com)

\title{
A rendezvények és kongresszusok híranyagának leadása
}

\author{
a lap megjelenése előtt legalább 40 nappal lehetséges, a 6 hetes nyomdai átfutás miatt. \\ Kérjük megrendelőink szíves megértését.
}

A híranyagokat a következő címre kérjük:

Orvosi Hetilap titkársága: edit.budai@akademiai.hu

Akadémiai Kiadó Zrt. 